\title{
ANALYZE BANKING EFFICIENCY FROM AN INTERNATIONAL PERSPECTIVE
}

\author{
John Wang, Montclair State University, prof.johnwang@gmail.com \\ Bin Zhou, University of Houston-Downtown,drbinzhou@yahoo.com \\ Ruiliang Yan, Texas A\&M University-Commerce, ruiliangy@gmail.com
}

\begin{abstract}
In this paper we study the performance and the efficiency of the banking sectors from an international perspective. Exploring key factors influencing bank profitability is of crucial importance to improve bank internal management and implement effective banking policies. A mathematical evaluation method is proposed for this study. This method is easy to apply and uses a linear programming model. The weights for various measurements are determined by objective method and are standard. The method is illustrated with real data from twenty-five developed countries worldwide.
\end{abstract}

Keywords: Banking Sector, Productivity, Performance and Efficiency, Linear Programming

\section{INTRODUCTION}

The recent widespread financial crisis, or the "Great Recession", in the global banking markets has taught us many lessons. One of the key lessons is that a healthy banking sector is of crucial importance to the overall performance of the economy and its stability. Given its intermediary role of mobilizing savings and channeling funds to borrowers, the banking system promotes investment in the real sector, such as investment in plant and equipment, new technologies, human capital and housing. In other words, a better functioning banking system may ease the external financing constraints that impede firms and industrial expansion.

The above view can be further explained by the fact that the efficiency of banking institutions are determined by a combination of factors that are related to the individual bank companies as well as to the institutional environment in which the banks operate. Although most studies examine only bank-specific factors within individual countries, there is a growing body of literature that considers how the variations in the operating environment of the banks affect their performance. To explore the cross-sectional differences in the operating environmental, several researchers have examined the banking efficiency scores across countries. For instance, Berg et al. [4] compare bank performance across Norway, Sweden, and Finland using Data Envelopment Analysis (DEA). Holló and Nagy [14], also estimated the cost efficiency for 2459 banks in 25 EU countries over the period 1998-2003. More recently, Bems and Sorsa [10] also compared the cost efficiency of 594 banks in 16 countries over period 1995-2007.

The common denominator of the cross-country studies is that the country in which the individual bank companies resides is a more important determinant of how the bank is operated than its industry affiliation. This in turn suggests that variations in county level institutional factors are likely to have a significant effect on banking performance. To investigate this possibility in more detail, we will examine the extent to which current crosscountry differences in banking sector efficiency can be explained by differences the in each country's legal environment, macroeconomic environment, accessibility to banking system, the size of each country's banking sector, and the profitability and efficiency indicators of the banking system.

This paper focuses on the international comparison of banking efficiency of 25 industrialized OECD countries. The study builds on recent literature in two important ways. First, our international comparison is based on the analysis of a number of important institutional characteristics within a single framework not entirely explored by previous researchers. Second, by taking a closer look in the efficiency of the banking sector, we are able to identify and explain the variation in bank sector performance that by considering five key factors influencing bank efficiency. We believe that this study would help to improve bank internal management and help governments to implement effective banking policies. 


\section{Issues in Information Systems \\ Volume 13, Issue 1, pp. 371-381, 2012}

\section{LITERATURE REVIEW}

Although efficiency analysis has already been applied to other industries such as hospitals, railroad, and electricity, it was introduced into the banking industry rather late, around the early 1980s. This was during the time when increasingly competitive in the global environment forced banks to realize the importance of efficiency analysis. Since then, there has been a tremendous emphasis on the importance of improved efficiency in the banking sector. Due to the competitive environment, banks are now forced to operate closer to the "best-practice" frontier or the efficient production function.

Subsequently, banking efficiency research has received wide attention. Many studies have been conducted to measure the efficiency of financial institutions, particularly commercial banks [7]. Most of these studies have been geared towards investigation of U.S. banks, followed by European banks in a distant second place. These studies employ different efficiency concepts (cost, revenue, profit efficiencies). They also employed different efficiency measurements methods such as parametric and non-parametric. For example, Berger and Humphrey [6] compiled the results of 130 efficiency analysis studies on financial institutions in 21 countries. Their study confirmed that efficiency scores differ considerably across studies. Recently, Berger [5] investigated 100 studies that compare bank efficiencies across nations. The comparisons show that the studies differ in terms of how efficiency is measured.

In general, most of the bank efficiency studies try to address two major questions. First, they estimate efficiency concepts (cost, revenue, profit) of banks, and second, they try to identify variables (also called correlates) that could explain some of the variations in efficiencies across banks. Hence, these studies on bank efficiency have investigated and tested potential correlates that explain some of the differences in efficiencies among banks and across countries. Dietsch and Lozano-Vivas [12] were one of the first researchers to investigate the variables that could explain cross-country differences in efficiency scores. The authors identified three groups of environmental variables: main conditions, bank structure and size, and regulation, and accessibility of banking services. Our research draw our selected efficiency correlates from this study. We will discuss these correlates in a broadspectrum.

\section{RESEARCH METHODOLOGY}

To enhance the comparability of the banking efficiency across countries, we have selected a set of five indicators that captures the country level differences in banking efficiency. Specifically, the variable selected to account for the variations are (1) the quality of the legal environment within which banks operates, (2) the macroeconomic conditions existing in each country, (3) the accessibility and usage of the banking facilities and resources, (4) the structure and size of the banking system, and (5) the profitability and efficiency of the banking sector. Each category will be examined through multiple sub-categories consisting of performance measures that will rate various countries on the respective criteria.

The main resources for the data were obtained from the Organizations for Economic Co-operation and Development (OECD), the World Bank Group, the International Monetary Fund (IMF) and United Nations Development Program. Table 1 will provide the raw data for each category and the sub category. Based on the items decided upon in each category, appropriate measurements were decided upon by examining the data from the IMF and other sources.

The countries we chose for this study are industrialized nations that are the members of Organization for Economic Co-operation and Development. OECD consists of developed nations for which data was readily available. First, we will explain why each category was chosen and then examine the sub-categories within them.

\section{Quality of Legal Environment}

The legal environment in which banks operates shape bank management's policy and productivity. In countries where there are weak laws and enforcement processes, short term loans are more likely to dominate at the expense 


\section{Issues in Information Systems \\ Volume 13, Issue 1, pp. 371-381, 2012}

of long-term investments which are much needed for financial stability, economic development and sustainability. Qian and Strahan [20] found that countries with strong creditor protection seem to enhance loan availability as lenders are more likely to provide credit on favorable terms.

In this paper, we consider three indicators of the legal environment within which banks operates, namely (1) Strength of legal rights index ( $0=$ weak to $10=$ strong), (2) Ease of doing business index ( $1=$ most business-friendly regulations), and (3) Corruption Perception index ( 0 =highly corrupt to $10=$ highly clean). In the following discussion we will review how these factors influence banking efficiency.

The Strength of Legal Rights is an index developed by the World Bank to measure the degree to which collateral and bankruptcy laws protect the rights of borrowers and lenders and thus facilitate lending. The index ranges from 0 to 10, with higher scores indicating that these laws are better designed to expand access to credit. La Porta, Lopez-deSilanes, Shleifer and Vishny [17] found that certain countries with better investor and creditor protection laws have better financial development. This measure is positively related to banking efficiency as strong creditor protection seem to enhance loan availability as lenders are more likely to provide credit on favorable terms [20]. We therefore expect a positive relationship between Strength of legal index and banking efficiency.

Corruption is also another key factor influencing banking efficiency through it effect on shaping the legal system. We define corruption as the abuse of public office for personal gain. We would measure this variable using the Corruption Perceptions Index created by Transparency International, a global civil society organization leading the fight against corruption. This index ranks almost 200 countries by their perceived levels of corruption, as determined by expert assessments and opinion surveys. When corruption exists in a legal system, it affects the integrity of the system, and may destroy both the economic and financial environment. Beck, Demirguc-Kunt, and Levine [8] indicated that corruption is a major obstacle to firm growth. They also concluded that corruption in lending impedes the ability of firms to raise external finance. Based on these findings, we would expect that a highly corrupt country (low value of corruption index) is more likely to be associated with an inefficient banking system.

\section{Bank Size}

In this paper, Bank size refers to the aggregate size of the banking sector and the range of attributes that determine its effectiveness in meeting its clients request and expectations. An increase in bank size could reduce the cost of the credit banks provide. The reason is that, large bank size may benefit from improved efficiency associated with scale economies. One advantage of larger bank size is that the banks may be more diversified, which could reduce their costs of funding. Consequently, a potential cost of limiting the bank size is that it may prevent banks from enjoying improved efficiency from scale economies as well as raise the cost of credit as a result. Recent research data shows substantially stronger evidence of increasing returns to scale among large banks [21]. Many researchers [16, 13] confirm the relationship between performance (as measured by either costs or by profitability) and bank size and indicated that many commercial banks benefited from increasing returns to scale, regardless of ownership structure and branch banking restrictions. Pasiouras and Kosmidou [19] find a positive and significant relationship between the size and the profitability of a bank.

Our measure of size centers mainly on total deposits or total assets. We ascertained the overall size of the banking sector by expressing the value of its assets or deposits as a ratio of the gross domestic product (GDP). Using the GDP as a common denominator allows us to have a benchmark for cross-country comparison. We choose deposit because deposit-taking is a common function among all banks. Deposits are also the main source of banking activity, particularly providing loans and credit, and thus are associated with the performance of the banking sector. We measure the banking sector size using the following five ratios: Assets of Deposit Money Banks to GDP, Bank Deposits to GDP, Liquid Liabilities to GDP, Domestic credit provided by banking sector to GDP and Private Credit by Deposit Money Banks to GDP.

The ratio of the assets of deposit money banks to GDP measures the claims on the whole nonfinancial real sector by deposit money banks as a share of GDP. This ratio is defined as the total assets of the deposit money banks divided 


\section{Issues in Information Systems \\ Volume 13, Issue 1, pp. 371-381, 2012}

by GDP. The ratio reflects the overall level of development of the banking sector. That is, this ratio measures to what extent banking assets constitute a larger or smaller share of the GDP. We can expect a positive relationship between this ratio and banking efficiency. Abreu and Mendes [2] and Naceur [18] reasoned that well-capitalized banks face lower need to borrow from external sources and this helps them to lower their funding costs. Such advantage translates into better profitability.

The ratio of bank deposits to GDP refers to the total deposit, which is made up of all checking, savings, time deposits of the banking system to economic activity. This measure serves as a proxy for the supply of funds to banks, and it provides an indication of the amount of funds that are available to the banking sector for its lending activities. This ratio captures the liability side of the banks' balance sheet. These ratios tend to higher for highperforming banks [9].

The ratio of the liquid liabilities to GDP is the currency plus demand and interest-bearing liabilities of banks and other financial intermediaries to GDP. This ratio is commonly used as an indicator of the financial depth of the banking system. It is a much broader indicator of financial intermediation since it includes all banking and nonbanking financial institutions. This ratio also captures the liability side of the banks' balance sheet. These ratios tend to higher for high-performing banks [9].

The ratio of the domestic credit provided by banking sector to GDP is the loans given by banks to the private sector as a share of GDP. This ratio is used as a common measure of magnitude of the banking sector and an indication of how much credit is provided by the banking sector to the economy. Since it helps to determine the degree to which the banking sector provides credit to firms and household, we can expect a positive relationship between this ratio and banking efficiency. This ratio captures the assets side of the banks' balance sheet efficiency [9].

The ratio of private credit by the banking sector to GDP is the claim on the private sector by deposit money banks to GDP. It also measures the magnitude of the banking sector. This ratio also captures the assets side of the banks' balance sheet.

\section{Macroeconomic Conditions}

The economic environments within which the banking sectors are hosted are more likely to differ significantly across countries and this could influence the differences in the banking sector efficiency through many channels. For instance, differences in the per capita income and population density could produce significant differences in the demand for banking products and services and which in turn could alter the banking sector profitability [12].

The annual real GDP Growth rate is the growth of goods and services adjusted for inflation. There is a greater demand for banking services during periods of increasing real GDP growth. For example, the banks can increase their lending activities due to the low risk of default on loans during periods of real GDP growth, leading to a positive effect on banks performance. Higher growth rate of GDP seem to have a strong positive impact on the performance measures.

GDP per capita measures a country's standard of living. Countries with high in GDP per capita have better access to new technology than countries with low in GDP per capita. Since technological advancement have a positive impact in reducing total cost, the banking sector of countries with high in GDP per capita are able to acquire new technology to produce more output using the same or even less input. We therefore expect that an increase in GDP per capita (current US\$) may boost banking efficiency by lowering total cost and increasing profits. Dietsch and Lozano-Vivas [12] found out that countries with higher income per capita have a banking system that operates in a mature environment resulting in more competitive interest rates, profit margins and efficiency levels.

The population density (people per sq. $\mathrm{km}$ of land area) is the ratio of inhabitants per square kilometer. Banking services that supply in areas of low population density would generate higher banking costs, and at the same time 


\section{Issues in Information Systems \\ Volume 13, Issue 1, pp. 371-381, 2012}

would impede banks to obtain high efficiency levels [12]. We therefore expect a positive relationship between population density and banking efficiency.

The annual inflation rate measures the overall percent increases in the consumer price index for all goods and services. High inflation is generally associated with uncertainty about future inflation, this this persuade banks away from lending loan-term loans. Likewise, most countries use interest rate to target inflation, as a result, the regulatory agencies increases interest rate when inflation is expected to rise. Such measures not only reduce expenditure by firms and households, but also reduce borrowing, affecting bank profitability. Thus, inflation will adversely affects banks performance.

\section{Profitability and Efficiency Indicators}

We believe that the quality of the management of the banking institution form the basic foundation for achieving profitability and efficiency of a bank. Athanasoglou et al. [3] indicated that there is a positive correlation between superior management and a firms profit and market shares. When management quality is low, there would be lapses in monitoring of employees, and some employees will not exert their full effort. We expect that extremely bad management may be fatal to the banking sector and have an adverse effect on its efficiency.

The reason why we included this variable in our model is because a substantial proportion of the banks activities are directed by its management and these indicators are particularly useful in assessing the quality of the bank's management decisions and processes within the control of the bank managers. Generally, financial ratios are used to assess the performance of banks. An advantage of using financial ratios is that they provide a broader understanding of the bank's financial condition since they are constructed from accounting data contained on the bank's balance sheet and financial statement.

To measure the banking sector internal characteristics, we decided to utilize several banking sector accounting ratios. The set of ratios used comprises of (1) Bank Return on Assets (ROA), (2) Bank Return on Equity (ROE), (3) Net Interest Margin, ratio of Bank Credit to Deposits, and (4) the ratio of Banking Overhead costs to Total Assets. In the following discussion we will review how these factors influence banking efficiency.

The Net Interest Margin is the interest income minus interest expenses over total assets. It is defined as the net income accruing to the bank from non-interest activities (including fees, service charges, foreign exchange, and direct investment) divided by total assets. A higher level $\mathrm{s}$ of the net interest margin indicates lower levels of banking efficiency [9].

The ratio of Banking Overhead costs to Total Assets is the accounting value of a banks overhead cost as a share of its total assets. This ratio is used to provide information on differences in operation costs across the banking system. Banking overheads includes wages and salaries of employees as well as the cost of running banking facilities. A high ratio is expected to impact efficiency negatively since efficient banks are expected to operate at lower costs. Similarly, a lower ratio may impact performance positively, since the bank can use technology to lower operational cost by introducing automatic ways means of delivering services efficiency [9]. Furthermore, Athanasoglou et al., [3] also indicated that overhead costs are an important determinant of profitability where the higher the overhead costs in relation to the assets, the lower the profitability of a bank.

The return on assets (ROA) is defined as the banks' after tax profit divided by its total assets. We choose ROA as the key proxy for bank profitability since it is an indication of the operational efficiency of the bank. The ROA provides information about how much profits are generated on average by each unit of assets. Therefore the ROA is an indicator on how efficiently a bank is being run by it management. Chan and Karim [11], indicated that return on assets have a positive effect on profit efficiency.

The return on equity (ROE), is a measure of equity holder returns and the potential growth on their investment. From this relationship it follows that the lower the equity capital, the higher the ROE As regards the ROE, banks 


\section{Issues in Information Systems \\ Volume 13, Issue 1, pp. 371-381, 2012}

hold capital in order to prevent bank failure and meet bank capital requirements set by the regulatory authorities. However, they do not want to hold too much capital because by doing so they will lower the returns to equity holders.

\section{Bank Accessibility}

The number of commercial bank branches (per 100,000 adults) measures the demographic penetration of the banking sector in terms of access to the banks' physical outlets. Higher penetration means more branches and thus easier access to the banking system. We therefore expect a positive relationship between this ratio and banking efficiency. It is calculated by finding the ratio of the number of commercial bank branches in a country to the total population and multiplying the result by the result by 100,000 . The penetration of branches among the population is positively associated with deposit and credit penetration, eventually improving profitability [1].

The number of commercial bank branches (per $\mathbf{k m}^{2}$ ) measures the measures the geographic penetration of the banking sector in terms of access to the banks' physical outlets. Higher penetration means more branches and thus easier access to the banking system. It is calculated by finding the ratio of the number of commercial bank branches in a country to the total surface area of the country as measured by square kilometers $(\mathrm{km} 2)$.

The number of automated teller machines, ATMs (per 100,000 adults) measures the demographic penetration of the banking sector in terms of access to the banks' physical outlets. It is calculated by finding the ratio of the number of ATMs of commercial banks in the country at end of the year to the total population and multiplying the result by the result by 100,000 . Higher penetration means more branches and thus easier access to the banking system. We therefore expect a positive relationship between this ratio and banking efficiency.

The number of automated teller machines, ATMs $\left(\mathbf{p e r} \mathbf{k m}^{2}\right)$ measures the measures the geographic penetration of the banking sector in terms of access to the banks' physical outlets. Higher penetration means more branches and thus easier access to the banking system. It is calculated by finding the ratio of the number of ATMs of commercial banks in the country at end of the year to the total surface area of the country as measured by square kilometers $(\mathrm{km} 2)$.

Holden and El-Bannany [15] investigated how IT systems of banks affected bank profitability in the United Kingdom. They used the number of automated teller machines ATMs of commercial banks as proxy. They found that investment in IT systems as measured by the number of automated teller machines ATMs had a positive impact on bank profitability.

Bank concentration is a measure of the banking structure and it refers to the ratio of the assets of the three largest banks to the total assets of all commercial banks. The structure of the banking sector is determined by how much influence the large banks have on the conduct of the overall banking sector. When concentration is high, there is the possibility that only few but large banks dominate the banking sector. In this case, the few large banks may introduce monopolistic tendencies into the behavior of the banking sector, leading to the suppression of bank productivity. With the suppression of productivity comes an increase in prices and deterioration of service quality. Thus, we expect that high bank concentration will adversely affect efficiency in the banking sector. The connection between structure and performance is known as the Structure-Conduct-Performance paradigm.

\section{CONCLUSIONS}

There are numerous countries with high bank deposits as a percent of their overall GDP such as Australia, Japan, Netherlands, Spain, Luxembourg, Switzerland, and UK. The high bank deposits of these countries when considered in aggregate represent the highest of bank deposits to GDP in the world but the data presented in table 1 confirms that each of these countries takes in a considerable amount of funds when compared against their GDP from their clientele, however the question becomes does these higher level of deposits translate into better performance or higher level efficiencies for the banks in their home countries. A look at the efficiency and profitability categories 


\section{Issues in Information Systems \\ Volume 13, Issue 1, pp. 371-381, 2012}

available in table 3 reveal that countries with a higher deposit to GDP are also among the ones with higher level of performance in terms of profitability and efficiency but to say that there is a direct relationship between high bank deposits to profitability and efficiency might not be entirely accurate because further look at the figures for table 3 in efficiency and profitability indicators reveal that other countries such as Denmark, Canada, Finland, Hungary, France, Greece, Ireland, Korea, Sweden, Turkey, New Zealand, Poland and the United States also have higher marks.

In summary, countries can gain insight from this study especially developed countries like U.S, Luxembourg, Switzerland, which have very established stringent banking laws and see how decoupling some of those laws may lead to better investments and access to other markets and instruments that may translate to better returns and efficiencies in turning deposits into profits and return on investments.

\section{REFERENCES}

1. Abdullah, Z. (1985). A Critical Review of the Impact of ATMs in Malaysia. Banker's Journal Malaysia, 28, 13-16.

2. Abreu, M., \& Mendes, V. (2002). Commercial Bank Interest Margins and Profitability: Evidence from E.U. Countries. Working Paper Series, Porto.

3. Athanasoglou, P., Brissimis, S., \& Delis, M., (2008). Bank-specific, industry-specific and macroeconomic determinants of bank profitability. Journal of International Financial Markets, Institutions and Money, 18 (2), 121-136.

4. Berg, S., Førsund, F., Hjalmarson, L. and Suominen, M. (1993). Banking Efficiency in the Nordic Countries. Journal of Banking and Finance, 17, 371-88.

5. Berger, A.N. (2007). International Comparisons of Banking Efficiency. Financial Markets, Institutions \& Instruments, 16, 119- 144.

6. Berger, A.N. \& Humphrey, D.B. (1997). Efficiency of Financial Institutions: International Survey and Directions for Future Research. European Journal of Operational Research, 98, 175 -212.

7. Berger, A.N. \& Mester, L. (2003). Explaining the Dramatic Changes in Performance of US Banks: Technological Change, Deregulation, and Dynamic Changes in Competition. Journal of Financial Intermediation, 12, 57-95.

8. Beck, T., Demirguc-Kunt, A. \& Levine, R. (2006). Bank supervision and corruption in lending. Journal of Monetary Economics, Elsevier, 53(8), 2131-2163.

9. Beck, T.H.L., Demirgüc-Kunt, A., \& Levine, R. (2010). Financial institutions and markets across countries and over time: The updated financial development and structure database. World Bank Economic Review, 24(1), 7792.

10. Bems, R. \& P. Sorsa (2008). Efficiency of the Slovene Banking Sector in the EU context. Journal for Money and Banking (Bančni Vestnik), 57 (11), November.

11. Chan, S. \& Karim M. (2010). Bank efficiency, profitability and equity capital: evidence from developing countries. American Journal of Finance and Accounting, 2 (2) 181-195.

12. Dietsch, M. \& Lozano-Vivas, A. (2000). How the Environment Determines Banking Efficiency: A comparison between French and Spanish industries. Journal of Banking and Finance, 24, 985-1004.

13. Feng, G. \& Serletis, A. (2010). Efficiency, Technical Change, and Returns to Scale in Large US Banks: Panel Data Evidence from an Output Distance Function Satisfying Theoretical Regularity. Journal of Banking \& Finance, 34(1), 127-138.

14. Holló, D. \& Nagy, M. (2006). Bank Efficiency in the Enlarged European Union. MNB Working Papers, No. 2006/3, Magyar Nemzeti Bank, Budapest.

15. Holden, K. \& El-Bannany, M. (2006). Investment in Information Technology Systems and Other Determinants of Bank Profitability in the UK. Paper retrieved on May 10, 2012 from http://www.clicktoconvert.com.

16. Hughes, J. P., Mester, L. J., \& Moon, C. (2001). Are Scale Economies in Banking Elusive or Illusive?: Evidence obtained by Incorporating Capital Structure and Risk-Taking into Models of Bank Production. Journal of Banking \& Finance, 25 (12), 2169-2208. 


\section{Issues in Information Systems}

Volume 13, Issue 1, pp. 371-381, 2012

17. La Porta, R., Lopez-de-Silanes, F., Shleifer, A. \& Vishny, R. (1997). Legal Determinants of External Finance. The Journal of Finance, 52(3), 1131-1150.

18. Naceur, S. (2003). The Determinants of the Tunisian Banking Industry Profitability: Panel Evidence, Working Paper. Retrieved Aug.24, 2011 from http://www.mafhoum.com/press6/174E11.pdf

19. Pasiouras, F., \& Kosmidou, K. (2007). Factors influencing the profitability of domestic and foreign commercial banks in the European Union. Research in International Business and Finance, 21 (2), 222-237.

20. Qian, J. \& Strahan, P. (2007). How Laws and Institutions Shape Financial Contracts: The Case of Bank Loans. The Journal of Finance, 62(6), 2803-2834.

21. Wheelock, D. \& Wilson, P. (2009). Are U.S. Banks Too Large? Working paper, 2009-054-A, Federal Reserve Bank of St. Louis Research Division. 


\section{Issues in Information Systems}

Volume 13., Issue No., pp. No., 2012

\section{RESULTS}

TABLE 1: RAW DATA (2009)

\begin{tabular}{|c|c|c|c|c|c|c|c|c|c|c|c|c|c|c|c|c|c|c|c|c|c|c|}
\hline & \multicolumn{4}{|c|}{ Macroeconomic Conditions } & \multicolumn{3}{|c|}{ Quality of Local Environment } & \multicolumn{5}{|c|}{ Efficiency and Profitability Indicators } & \multicolumn{5}{|c|}{ Size of Banking Sector } & \multicolumn{5}{|c|}{ Bank Accessibility \& Usage } \\
\hline & 1.1 & 1.2 & 1.3 & 1.4 & 2.1 & 2.1 & 2.3 & 3.1 & 3.2 & 3.3 & 3.4 & 3.5 & 4.1 & 4.2 & 4.3 & 4.4 & 4.5 & 5.1 & 5.2 & 5.3 & 5.4 & 5.5 \\
\hline $\mathbf{A U}$ & 42278.74 & -0.76 & 2.85 & 1.82 & 9.00 & 10.00 & 8.70 & 1.00 & 0.01 & 0.02 & 0.00 & 0.14 & 1.29 & 1.14 & 1.19 & 143.63 & 1.29 & 0.72 & 31.39 & 3.53 & 153.03 & 5.00 \\
\hline AS & 45561.86 & -4.20 & 101.44 & 0.49 & 7.00 & 31.00 & 7.90 & 1.09 & 0.03 & 0.03 & 0.01 & 0.07 & 1.22 & 0.92 & 1.00 & 141.12 & 1.12 & 10.13 & 11.81 & 41.30 & 48.00 & 7.00 \\
\hline BE & 43671.48 & -3.47 & 356.30 & -0.05 & 7.00 & 22.00 & 7.10 & 1.20 & 0.01 & 0.05 & 0.27 & 0.19 & 1.15 & 0.96 & 1.04 & 119.35 & 1.04 & 142.17 & 47.96 & 256.04 & 86.37 & 4.50 \\
\hline CA & 39599.04 & -3.70 & 3.71 & 0.30 & 6.00 & 9.00 & 8.90 & 2.04 & 0.02 & 0.02 & 0.01 & 0.25 & 1.40 & 1.04 & 1.06 & 169.40 & 1.30 & 0.74 & 23.99 & 6.66 & 215.14 & 5.70 \\
\hline DE & 55870.89 & -5.82 & 130.32 & 1.33 & 9.00 & 6.00 & 9.30 & 3.11 & 0.03 & 0.02 & 0.01 & 0.06 & 2.42 & 0.72 & 0.75 & 22.97 & 2.28 & 48.79 & 44.77 & 69.43 & 63.15 & 5.70 \\
\hline FI & 44580.70 & -8.63 & 17.57 & 0.00 & 7.00 & 11.00 & 9.20 & 1.48 & 0.01 & 0.01 & 0.03 & 1.80 & 0.86 & 0.52 & 0.59 & 98.66 & 0.84 & 2.19 & 14.97 & 13.43 & 91.72 & 6.40 \\
\hline FR & 40663.05 & -3.26 & 117.85 & 0.08 & 7.00 & 28.00 & 6.80 & 1.64 & 0.02 & 0.02 & 0.01 & 0.12 & 1.27 & 0.69 & 0.76 & 128.38 & 1.15 & 40.36 & 43.26 & 100.29 & 107.49 & 4.50 \\
\hline GE & 40669.67 & -4.45 & 234.86 & 0.31 & 7.00 & 21.00 & 7.90 & 0.86 & 0.02 & 0.04 & 0.01 & 0.13 & 1.15 & 1.07 & 1.15 & 131.84 & 0.98 & 33.77 & 16.63 & 237.22 & 116.80 & 4.80 \\
\hline GR & 28935.11 & -2.45 & 87.54 & 1.21 & 3.00 & 97.00 & 3.50 & 1.13 & 0.02 & 0.02 & 0.00 & 0.18 & 1.08 & 0.90 & 0.97 & 112.72 & 1.02 & 30.96 & 41.23 & 58.75 & 78.00 & 6.10 \\
\hline HU & 12847.75 & -6.54 & 111.84 & 4.21 & 7.00 & 52.00 & 4.70 & 1.61 & 0.08 & 0.26 & -0.05 & 0.03 & 0.90 & 0.50 & 0.61 & 79.88 & 0.70 & 16.66 & 17.49 & 52.99 & 55.62 & 8.50 \\
\hline IR & 49832.88 & -8.09 & 64.60 & -4.48 & 7.00 & 8.00 & 8.00 & 2.52 & 0.01 & 0.02 & 0.00 & 0.00 & 2.33 & 1.00 & 1.05 & 219.78 & 2.44 & 17.84 & 34.81 & 49.30 & 96.18 & 5.60 \\
\hline IT & 35.056 .72 & -5.83 & 204.74 & 0.77 & 3.00 & 76.00 & 3.90 & 1.25 & 0.03 & 0.01 & 0.00 & 0.04 & 1.40 & 0.74 & 0.83 & 141.60 & 1.09 & 118.89 & 67.66 & 184.58 & 105.04 & 8.00 \\
\hline JA & 39455.81 & -6.18 & 349.96 & -1.35 & 8.00 & 19.00 & 7.80 & 0.51 & 0.02 & 0.01 & 0.00 & 0.00 & 1.48 & 1.80 & 1.92 & 320.53 & 0.93 & 102.89 & 33.93 & 403.23 & 132.96 & 4.70 \\
\hline ко & 17109.99 & 0.03 & 502.96 & 2.83 & 7.00 & 15.00 & 5.40 & 2.14 & 0.03 & 0.01 & 0.01 & 0.56 & 1.21 & 0.59 & 0.60 & 112.35 & 1.16 & 77.14 & 18.47 & 1047.68 & 250.29 & 10.90 \\
\hline $\mathbf{L U}$ & 106237.09 & -5.42 & 192.22 & 0.37 & 7.00 & 42.00 & 8.50 & 0.61 & 0.01 & 0.01 & 0.00 & 0.12 & 2.66 & 4.72 & 4.78 & 188.55 & 2.61 & 148.65 & 94.07 & 180.69 & 114.35 & 6.00 \\
\hline ME & 8217.23 & -7.02 & 55.26 & 5.30 & 5.00 & 41.00 & 3.10 & 0.87 & 0.04 & 0.21 & -5.16 & -0.23 & 0.38 & 0.23 & 0.27 & 44.09 & 0.22 & 5.71 & 14.46 & 17.39 & 44.00 & 9.70 \\
\hline $\mathrm{NE}$ & 48065.72 & -4.41 & 489.67 & 1.19 & 6.00 & 29.00 & 8.80 & 1.72 & 0.02 & 0.05 & 0.93 & 0.32 & 2.15 & 1.28 & 1.36 & 224.43 & 2.09 & 101.66 & 25.25 & 251.95 & 62.58 & 4.30 \\
\hline $\mathrm{NZ}$ & 29352.45 & 0.31 & 16.39 & 1.89 & 10.00 & 3.00 & 5.30 & 1.61 & 0.02 & 0.01 & 0.01 & 0.49 & 1.55 & 0.96 & 1.06 & 154.16 & 1.58 & 4.63 & 35.47 & 9.40 & 72.11 & 6.81 \\
\hline PO & 11288.42 & 1.59 & 125.40 & 3.83 & 9.00 & 73.00 & 5.30 & 1.31 & 0.03 & 0.02 & 0.02 & 0.18 & 0.55 & 1.42 & 0.49 & 61.53 & 0.47 & 49.20 & 46.14 & 52.21 & 48.95 & 9.00 \\
\hline SP & 31857.33 & -4.56 & 92.08 & -0.40 & 6.00 & 48.00 & 6.10 & 1.45 & 0.01 & 0.01 & 0.00 & 0.23 & 2.17 & 1.56 & 1.62 & 228.39 & 2.14 & 30.04 & 38.30 & 120.49 & 153.63 & 6.80 \\
\hline SE & 43389.34 & -6.17 & 22.67 & -0.28 & 5.00 & 18.00 & 9.20 & 2.47 & 0.02 & 0.01 & 0.01 & 0.16 & 1.40 & 0.57 & 0.59 & 143.82 & 1.32 & 0.22 & 22.79 & 8.09 & 36.94 & 5.00 \\
\hline $\mathbf{T U}$ & 8214.24 & -5.97 & 97.21 & 6.25 & 4.00 & 60.00 & 4.40 & 0.86 & 0.04 & 0.04 & 0.02 & 0.52 & 0.51 & 0.42 & 0.45 & 63.01 & 0.37 & 12.37 & 17.38 & 31.12 & 43.74 & 13.30 \\
\hline SW & 63628.71 & -2.97 & 193.28 & -0.48 & 8.00 & 24.00 & 8.70 & 1.45 & 0.02 & 0.03 & 0.01 & 0.12 & 1.89 & 1.31 & 1.40 & 190.99 & 1.81 & 86.43 & 52.81 & 155.70 & 95.15 & 5.50 \\
\hline UK & 35142.61 & -5.54 & 255.60 & -0.55 & 9.00 & 4.00 & 7.60 & 1.26 & 0.01 & 0.01 & 0.00 & 0.07 & 2.08 & 1.71 & 1.66 & 228.90 & 2.07 & 53.83 & 25.51 & 136.27 & 64.58 & 5.40 \\
\hline US & 45744.56 & -3.50 & 33.56 & -0.36 & 8.00 & 5.00 & 7.10 & 0.75 & 0.04 & 0.04 & 0.01 & 0.06 & 0.73 & 0.83 & 0.77 & 230.50 & 0.66 & 9.59 & 35.87 & 46.46 & 173.75 & 11.00 \\
\hline
\end{tabular}

AU - Australia, AS - Austria, BE - Belgium, CA - Canada, DE - Denmark, FI - Finland, FR - France, GE - Germany, GR - Greece, HU - Hungary, IR - Ireland, IT - Italy, JA - Japan, KO - Korea, LU - Luxemburg, ME - Mexico, NE Netherlands, NZ - New Zealand, PO - Poland, SP - Spain, SE - Sweeden, TU -Turkey, SW - Switzerland, UK - United Kingdom, US - United States

Note 2:
1.1 - GDP per Capita (Current US\$). 1.2 - GDP per Capita Growth (Annual \%). 1.3 - Population Density (People per sq. km of land area). $1.4-$ Inflation, consumer prices (annual \%). 2.1 - Strength of legal rights index (0=weak to 10=strong). 2.2

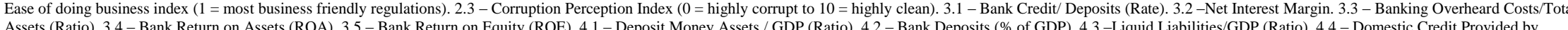
Banking Sector (\% of GDP). 4.5 - Private Credit by Deposit Money Bank/GDP (Ratio). 5.1 - Number of Commercial Bank Branches (per $\left.1000 \mathrm{~km}^{2}\right)$. 5.2 - Number of Commerical Bank Branches (per 100,000 adults). 5.3 - Number of ATMs (per $\left.1000 \mathrm{~km}^{2}\right) .5 .4$ - Number of ATMs (per 100,000 adults). 5.5 - Bank Concentration 


\section{Issues in Information Systems \\ Volume 13, Issue 1, pp. 371-381, 2012}

TABLE 2 RANKED DATA $(0-9)$

\begin{tabular}{|c|c|c|c|c|c|c|c|c|c|c|c|c|c|c|c|c|c|c|c|c|c|c|}
\hline & \multicolumn{4}{|c|}{ Macroeconomic Conditions } & \multicolumn{3}{|c|}{$\begin{array}{c}\text { Quality of Local } \\
\text { Environment }\end{array}$} & \multicolumn{5}{|c|}{ Efficiency and Profitability Indicators } & \multicolumn{5}{|c|}{ Size of Banking Sector } & \multicolumn{5}{|c|}{ Bank Accessibility \& Usage } \\
\hline & 1.1 & 1.2 & 1.3 & 1.4 & 2.1 & 2.1 & 2.3 & 3.1 & 3.2 & 3.3 & 3.4 & 3.5 & 4.1 & 4.2 & 4.3 & 4.4 & 4.5 & 5.1 & 5.2 & 5.3 & 5.4 & 5.5 \\
\hline $\mathbf{A U}$ & 3.13 & 6.93 & 0.00 & 3.72 & 7.71 & 8.33 & 8.13 & 1.69 & 0.56 & 8.75 & 7.63 & 1.63 & 3.56 & 1.83 & 1.83 & 3.24 & 4.02 & 0.03 & 2.14 & 0.00 & 4.90 & 8.30 \\
\hline AS & 3.43 & 3.90 & 1.77 & 4.83 & 5.14 & 6.32 & 6.97 & 2.02 & 2.46 & 8.37 & 7.64 & 1.32 & 3.29 & 1.38 & 1.45 & 3.16 & 3.39 & 0.60 & 0.00 & 0.33 & 0.47 & 6.30 \\
\hline BE & 3.26 & 4.54 & 6.36 & 5.89 & .5 .14 & 7.18 & 5.81 & 2.39 & 0.39 & 7.62 & 8.02 & 1.85 & 3.04 & 1.47 & 1.53 & 2.45 & 3.09 & 8.61 & 3.96 & 2.18 & 2.09 & 8.80 \\
\hline CA & 2.88 & 4.34 & 0.02 & 4.99 & 3.86 & 8.43 & 8.42 & 5.30 & 1.20 & 8.69 & 7.64 & 2.12 & 4.02 & 1.62 & 1.58 & 4.08 & 4.05 & 0.03 & 1.33 & 0.03 & 7.52 & 7.60 \\
\hline DE & 4.38 & 2.48 & 2.29 & 4.13 & 7.71 & 8.71 & 9.00 & 9.00 & 2.29 & 8.42 & 7.63 & 1.28 & 8.05 & 0.99 & 0.95 & 5.82 & 7.75 & 2.95 & 3.61 & 0.57 & 1.11 & 7.60 \\
\hline FI & 3.34 & 0.00 & 0.26 & 5.24 & 5.14 & 8.23 & 8.85 & 3.37 & 0.32 & 8.93 & 7.67 & 9.00 & 1.90 & 0.59 & 0.63 & 1.78 & 2.32 & 0.12 & 0.35 & 0.09 & 2.31 & 6.90 \\
\hline FR & 2.98 & 4.73 & 2.07 & 5.17 & 5.14 & 6.61 & 5.37 & 3.91 & 1.66 & 8.47 & 7.63 & 1.56 & 3.51 & 0.93 & 0.99 & 2.74 & 3.49 & 2.43 & 3.44 & 0.83 & 2.98 & 8.80 \\
\hline GE & 2.98 & 3.68 & 4.18 & 4.98 & 5.14 & 7.28 & 6.97 & 1.20 & 1.98 & 7.71 & 7.64 & 1.59 & 3.03 & 1.68 & 1.75 & 2.86 & 2.86 & 2.03 & 0.53 & 2.01 & 3.37 & 8.50 \\
\hline GR & 1.90 & 5.45 & 1.52 & 4.23 & 0.00 & 0.00 & 0.58 & 2.16 & 1.54 & 8.62 & 7.63 & 1.83 & 2.76 & 1.34 & 1.40 & 2.23 & 3.01 & 1.86 & 3.22 & 0.48 & 1.73 & 7.20 \\
\hline $\mathrm{HU}$ & 0.43 & 1.84 & 1.96 & 1.71 & 5.14 & 4.31 & 2.32 & 3.82 & 9.00 & 0.00 & 7.55 & 1.14 & 2.06 & 0.55 & 0.67 & 1.17 & 1.80 & 1.00 & 0.62 & 0.43 & 0.79 & 4.80 \\
\hline IR & 3.82 & 0.48 & 1.11 & 9.00 & 5.14 & 8.52 & 7.11 & 6.95 & 0.91 & 8.49 & 7.63 & 1.01 & 7.69 & 1.54 & 1.55 & 5.72 & 8.33 & 1.07 & 2.52 & 0.39 & 2.50 & 7.70 \\
\hline IT & 2.46 & 2.47 & 3.63 & 4.59 & 0.00 & 2.01 & 1.16 & 2.56 & 2.40 & 8.79 & 7.63 & 1.20 & 4.01 & 1.03 & 1.11 & 3.17 & 3.29 & 7.20 & 6.11 & 1.56 & 2.87 & 5.30 \\
\hline JA & 2.87 & 2.16 & 6.25 & 6.38 & 6.43 & 7.47 & 6.82 & 0.00 & 0.97 & 8.85 & 7.63 & 1.01 & 4.34 & 3.15 & 3.29 & 9.00 & 2.68 & 6.23 & 2.42 & 3.45 & 4.05 & 8.60 \\
\hline ко & 0.82 & 7.63 & 9.00 & 2.87 & 5.14 & 7.85 & 3.34 & 5.64 & 2.38 & 8.88 & 7.64 & 3.50 & 3.27 & 0.72 & 0.67 & 2.22 & 3.54 & 4.66 & 0.72 & 9.00 & 9.00 & 2.40 \\
\hline $\mathbf{L U}$ & 9.00 & 2.83 & 3.41 & 4.93 & 5.14 & 5.27 & 7.84 & 0.36 & 0.00 & 8.87 & 7.63 & 1.53 & 9.00 & 9.00 & 9.00 & 4.70 & 9.00 & 9.00 & 9.00 & 1.53 & 3.27 & 7.30 \\
\hline ME & 0.00 & 1.42 & 0.94 & 0.80 & 2.57 & 5.36 & 0.00 & 1.24 & 3.82 & 1.77 & 0.00 & 0.00 & 0.00 & 0.00 & 0.00 & 0.00 & 0.00 & 0.33 & 0.29 & 0.12 & 0.30 & 3.60 \\
\hline $\mathrm{NE}$ & 3.66 & 3.72 & 8.76 & 4.24 & 3.86 & 6.51 & 8.27 & 4.18 & 1.85 & 7.58 & 9.00 & 2.43 & 6.98 & 2.11 & 2.17 & 5.87 & 7.04 & 6.15 & 1.47 & 2.14 & 1.08 & 9.00 \\
\hline $\mathrm{NZ}$ & 1.94 & 7.33 & 0.24 & 3.66 & 9.00 & 9.00 & 3.19 & 3.82 & 1.74 & 8.85 & 7.64 & 3.17 & 4.59 & 1.46 & 1.58 & 3.58 & 5.11 & 0.27 & 2.59 & 0.05 & 1.48 & 6.49 \\
\hline PO & 0.28 & 9.00 & 2.21 & 2.03 & 7.71 & 2.30 & 3.19 & 2.77 & 2.22 & 8.52 & 7.65 & 1.81 & 0.68 & 0.38 & 0.44 & 0.57 & 0.97 & 2.97 & 3.76 & 0.42 & 0.51 & 4.30 \\
\hline $\mathbf{S P}$ & 2.17 & 3.58 & 1.61 & 5.58 & 3.86 & 4.69 & 4.35 & 3.27 & 0.19 & 9.00 & 7.63 & 2.05 & 7.04 & 2.66 & 2.69 & 6.00 & 7.23 & 1.81 & 2.90 & 1.01 & 4.92 & 6.50 \\
\hline SE & 3.23 & 2.17 & 0.36 & 5.48 & 2.57 & 7.56 & 8.85 & 6.79 & 1.87 & 8.96 & 7.64 & 1.72 & 4.01 & 0.68 & 0.64 & 3.25 & 4.15 & 0.00 & 1.20 & 0.04 & 0.00 & 8.30 \\
\hline $\mathbf{T U}$ & 0.00 & 2.34 & 1.70 & 0.00 & 1.29 & 3.54 & 1.89 & 1.22 & 4.43 & 7.96 & 7.66 & 3.31 & 0.51 & 0.39 & 0.36 & 0.62 & 0.58 & 0.74 & 0.61 & 0.24 & 0.29 & 0.00 \\
\hline SW & 5.09 & 4.99 & 3.43 & 5.65 & 6.43 & 6.99 & 8.13 & 3.25 & 1.84 & 8.19 & 7.64 & 1.55 & 5.94 & 2.18 & 2.25 & 4.78 & 5.97 & 5.23 & 4.49 & 1.31 & 2.46 & 7.80 \\
\hline UK & 2.47 & 2.73 & 4.55 & 5.71 & 7.71 & 8.90 & 6.53 & 2.59 & 0.19 & 8.99 & 7.63 & 1.30 & 6.68 & 2.97 & 2.78 & 6.02 & 6.97 & 3.25 & 1.50 & 1.14 & 1.17 & 7.90 \\
\hline US & 3.45 & 4.52 & 0.55 & 5.54 & 6.43 & 8.81 & 5.81 & 0.85 & 3.72 & 8.00 & 7.64 & 1.28 & 1.37 & 1.21 & 0.99 & 6.07 & 1.64 & 0.57 & 2.63 & 0.37 & 5.77 & 2.30 \\
\hline
\end{tabular}

AU - Australia, AS - Austria, BE - Belgium, CA - Canada, DE - Denmark, FI - Finland, FR - France, GE - Germany, GR - Greece, HU - Hungary, IR - Ireland, IT - Italy, JA - Japan, KO - Korea, LU - Luxemburg, ME Mexico, NE - Netherlands, NZ - New Zealand, PO - Poland, SP - Spain, SE - Sweeden, TU - Turkey, SW - Switzerland, UK - United Kingdom, US - United States

Note 2:

1.1 - GDP per Capita (Current US\$). 1.2 - GDP per Capita Growth (Annual \%). 1.3 - Population Density (People per sq. km of land area). 1.4 - Inflation, consumer prices (annual \%). 2.1 - Strength of legal rights index (0=weak

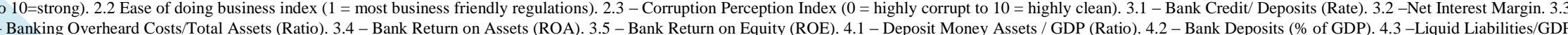




\section{Issues in Information Systems \\ Volume 13, Issue 1, pp. 371-381, 2012}

TABLE 3 Converted Scores

\begin{tabular}{|c|c|c|c|c|c|c|}
\hline Country & $\begin{array}{c}\text { Macroeconomic } \\
\text { Conditions }\end{array}$ & $\begin{array}{c}\text { Quality of Legal } \\
\text { Environment }\end{array}$ & $\begin{array}{c}\text { Bank Management } \\
\text { Quality }\end{array}$ & $\begin{array}{c}\text { Size of Banking } \\
\text { Sector }\end{array}$ & $\begin{array}{c}\text { Accessibility and } \\
\text { usage of banks }\end{array}$ & Average \\
\hline Australia & 100.00 & 98.01 & 98.56 & 53.47 & 99.44 & 89.90 \\
\hline Austria & 82.69 & 77.42 & 97.43 & 48.93 & 70.00 & 75.29 \\
\hline Belgium & 100.00 & 81.09 & 94.23 & 40.80 & 100.00 & 83.22 \\
\hline Canada & 87.90 & 96.47 & 98.33 & 61.20 & 100.00 & 88.78 \\
\hline Denmark & 70.48 & 100.00 & 100.00 & 100.00 & 86.93 & 91.48 \\
\hline Finland & 65.53 & 98.39 & 100.00 & 29.71 & 78.38 & 74.40 \\
\hline France & 92.99 & 74.63 & 97.02 & 45.86 & 100.00 & 82.10 \\
\hline Germany & 85.94 & 83.06 & 92.78 & 43.58 & 97.59 & 80.59 \\
\hline Greece & 89.61 & 6.45 & 97.86 & 38.28 & 81.82 & 62.80 \\
\hline Hungary & 34.41 & 58.28 & 100.00 & 23.45 & 53.58 & 53.94 \\
\hline Ireland & 100.00 & 96.41 & 97.97 & 100.00 & 87.38 & 96.35 \\
\hline Italy & 72.90 & 22.48 & 99.48 & 52.13 & 81.94 & 65.79 \\
\hline Japan & 100.00 & 84.98 & 99.21 & 100.00 & 100.00 & 96.84 \\
\hline Korea, Rep. & 100.00 & 87.41 & 100.00 & 41.36 & 100.00 & 85.75 \\
\hline Luxembourg & 100.00 & 87.10 & 99.25 & 100.00 & 100.00 & 97.27 \\
\hline Mexico & 20.71 & 59.57 & 53.68 & 0.00 & 40.00 & 34.79 \\
\hline Netherlands & 100.00 & 91.94 & 100.00 & 95.16 & 100.00 & 97.42 \\
\hline New Zealand & 100.00 & 100.00 & 99.45 & 65.52 & 73.49 & 87.09 \\
\hline Poland & 100.00 & 86.75 & 91.81 & 11.07 & 54.30 & 69.99 \\
\hline Spain & 88.12 & 53.44 & 100.00 & 97.33 & 84.83 & 84.74 \\
\hline Sweden & 75.78 & 98.39 & 100.00 & 53.81 & 92.22 & 84.04 \\
\hline Turkey & 28.44 & 39.56 & 100.00 & 9.20 & 8.85 & 37.21 \\
\hline Switzerland & 100.00 & 90.32 & 95.42 & 79.20 & 92.07 & 91.40 \\
\hline United States & 89.16 & 100.00 & 99.95 & 96.22 & 88.03 & 94.67 \\
\hline UK & 65.16 & 98.72 & 98.45 & 67.43 & 79.93 & 87.94 \\
\hline
\end{tabular}

(Ratio). 4.4 - Domestic Credit Provided by Banking Sector (\% of GDP). 4.5 - Private Credit by Deposit Money Bank/GDP (Ratio). 5.1 - Number of Commercial Bank Branches (per 1000 km²). 5.2 - Number of Commercial Bank Branches (per 100,000 adults). 5.3 - Number of ATMs (per $1000 \mathrm{~km}^{2}$ ). 5.4 - Number of ATMs (per 100,000 adults). 5.5 - Bank Concentration 